\title{
FANCM Gene Mutation
}

National Cancer Institute

\section{Source}

National Cancer Institute. FANCM Gene Mutation. NCI Thesaurus. Code C132004.

A change in the nucleotide sequence of the FANCM gene. 